International Journal of Engineering \& Technology, $7(2.27)(2018) 218-224$
International Journal of Engineering \& Technology
SPC
Website: www.sciencepubco.com/index.php/IJET
Research paper

\title{
Poverty level grouping using SAW method
}

\author{
Elisabet Yunaeti Anggraeni ${ }^{1}$, Miftachul Huda ${ }^{2}$, Andino Maseleno ${ }^{1,3 *}$, Jimaain Safar ${ }^{2}$, Kamarul Azmi Jasmi ${ }^{2}$, \\ Ahmad Kilani Mohamed ${ }^{2}$, Aminudin Hehsan ${ }^{2}$, Bushrah Basiron ${ }^{2}$, Siti Suhaila Ihwani ${ }^{2}$, Wan Hassan \\ Wan Embong ${ }^{2}$, Ahmad Marzuki Mohamad ${ }^{2}$, Sulaiman Shakib Mohd Noor ${ }^{2}$, \\ Almira Nabila Fauzi ${ }^{4}$, Dona Ari Wijaya ${ }^{1}$, M. Masrur ${ }^{1}$
}

${ }^{1}$ Department of Information Systems, STMIK Pringsewu, Lampung, Indonesia

${ }^{2}$ Faculty of Social Sciences and Humanities, Universiti Teknologi Malaysia, Malaysia

${ }^{3}$ Institute of Informatics and Computing Energy, Universiti Tenaga Nasional, Malaysia

${ }^{4}$ Faculty of Business, Monash University, Malaysia

*Corresponding author E-mail: andimaseleno@gmail.com

\begin{abstract}
Poverty is social gap problem for some people with below average income level but in Pringsewu district the poverty rate is significantly decreased so it is expected to increase the potential of Pringsewu region to be better, in increasing the potential of the region it needs a system that is expected to assist in determination of poverty level in sub district in Pringsewu by data clustering and ranking from every subdistrict in Pringsewu Regency using SAW method. Therefore, we are interested to build an application of Poverty Grouping in Pringsewu region in the form of Poverty Index of the last few years, existing data is expected to be a reference to increase the potential of the area by reducing the poverty rate every year. It is expected that the data obtained can be a reference of the government in reducing poverty level in subdistrics in Pringsewu District.
\end{abstract}

Keywords: Decision Support System; Poverty; Simple Additive Weighting; Criteria.

\section{Introduction}

\subsection{Background}

Pringsewu District is the smallest district located in Lampung province and its capital is Bandar Lampung, Pringsewu district is bordering with Tanggamus Regency. This district has been ratified into Pringsewu District during the plenary session of the House of Representatives on October 29, 2008 [1]. Pringsewu District consists of various ethnic groups and the most is Javanese community compared with the indigenous community of Lampung.

Pringsewu District has 9 sub-districts there are Gadingrejo, Pagelaran, Pardasuka, Pagelaran Utara, Sukoharjo, Banyumas, Adiluwih, Ambarawa and Pringsewu Sub-districts. Pringsewu District has 96 pekons and has 5 sub-districts spread in 9 subdistricts. The district of Pringsewu is the smallest district in Lampung Province [2]. The villages in Pringsewu District are mostly liveable, but there are also some areas that are still left behind, it is because the village is far from the center of Pringsewu city, so it is less attention, so it should get serious attention from the government

Currently Pringsewu District Government in grouping poverty level is still using manual method, that is, only by looking or direct survey of the village by doing manual calculation, so that the data obtained are less accurate, based on the data that have been taken by Government of Pringsewu Regency succeeded in decreasing poverty level each year, based on data from the Central Bureau of Statistics The Development of the Poverty Rate Index in Pringsewu District from 2010 to 2015, is as follows:

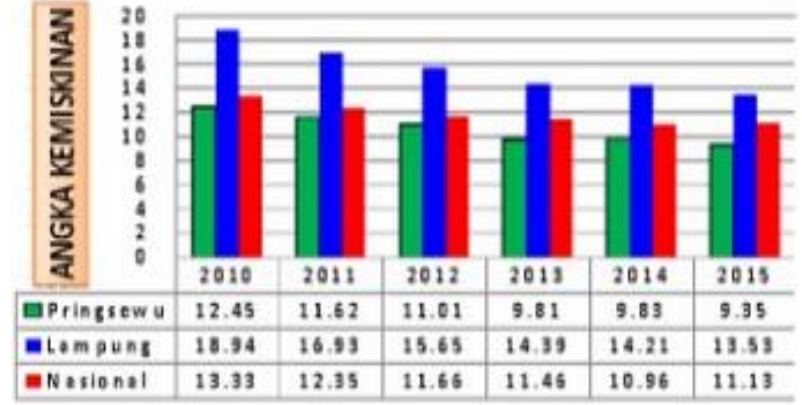

Fig. 1: Index of Poverty Rate of Pringsweu District Year 2010-2015 (Source: Https://Www.Pringsewukab.Go.Id/Visi-Misi-Bupati-Dan-WakilBupati-Pringsewu-Periode-2017-2022/, Accesed on 9 Desember 2017).

Based on the above data can be seen that the poverty rate that occurred in Pringsewu District in recent years has decreased. From the research conducted by Raihana Kaplale [1] entitled Factors Affecting Poverty Level in Ambon city, by studying the level of poverty in the economic strata of each household that covers the level of household expenditure and income level which then look for causes of poverty to know the amount of income to households in each village.

Research conducted by Uning Lestari, Muhammad Targiono entitled Decision Supporting System of Classification of Poor Family as Reference of Government Funds Receiver, by knowing the status of poor families to receive the fund, determining the weight value of each attribute by ranking process to know the category of poor family. Then these results can form the basis for the TPK (Poverty Reduction team) to determine which families 
are eligible for government funding so that the distribution of aid is on target.

\subsection{Problem formulation}

Based on that background then the problems to be faced are :

1) How to ranking poverty level on a subdistrict in Pringsweu District using Simple Additive Weighting (SAW method?

2) How to implement existing data to increase the potency of subdistrict in Pringsewu district.

\subsection{Research purpose}

The purposes of this research were :

1) To know poverty level in Pringsewu region in every year by data ranking in several years

2) To develop goverment data processing system because the current system is manual so it is need better and more integrated data processing.

3) With that application program it can increaase the potency of Pringsewu district for optimalizing data processing.

\subsection{Research benefit}

The benefits of this research are :

1) The results of this research are expected to be a reference for Pringsewu District goverment to decrease poverty level on subdistricts in Pringsewu District.

2) The results of research in the form of web application program is expected to be a solution to replace the system that has been running manually for better data input process

\section{Theoretical basis}

\subsection{Definition of poverty}

Poverty is a person's inability to meet basic needs such as food, clothing, education, shelter and health. Poverty is a Global problem which means anyone can experience it, some people are subjective and comparative in understanding this term and others seen evaluative and moral term and some others understand from a scientific point of form in the establishment, etc.

Poverty as a low standard of living, a lack of a number or a group of people compared to this low standard of living that directly influences their health, moral life and pride which is classified as pauper [3].

Poverty is a living conditions that are deprived of a person or household so unable to meet the minimal or decent needs for his life [3]. Some necessary tasks like minimum basic needs in question refers to the one based on food, clothing, housing and social needs required to meet their achievement professionally [10-12] and more ethically [13-15]with being engaged properly [16-18].

Based on the theoretical basis above, the system to be created in this application is Decision Support System to know the level of poverty of Pringsewu District in recent years.

\subsection{Internet}

Internet refers to the platform with expanding the abbreviation of international network, where the main component combined with an international network amidst the computers all over the world are related to one another [19-21]. At this point, the one computer with another computer could be seen such as TCP / IP, short for Transmission Control Protocol / Internet Protocol [4] [22][23].

PHP is one of the scipt programming languages designed to build web applications. When called from a web browser, a program written in PHP will be parsed in the Web Server by a PHP interpreter and translated into an HTML document, which will then be displayed back into Web Browser [8] [5] [24] [25]. PHP is a scripting server language that integrates with HTML to create dynamic web pages in order to gain the maximum achievement of the sources browsing using the digital device [26]-27].

The value to tackle this poverty issues refers to the initiative to face the obstacles through fulfilling their basic needs and education and work [28-30].

\subsection{Website}

Website is a method to display information on the Internet in the form of text, figure, sound, or video that is interactive and has the advantage to link (link) one to another document (hypertext) which can be accessed through a browser [6]. Web browser here could be gained with ethical and professional basis to underlie the process of transforming the data from Internet with appropriate and wise approach [31-34]. Such name domain within the particular group of web pages could be generally a part of the domain name (domain name) including the sub domain in the WWW (World Wide Web) on the Internet. WWW consists of all websites which are available to the public.

\subsection{Database}

Database refers to the number of collection about data interconnected along with the organization or enterprise with a variety of usage [6-7]. The data base is widely engaged into certain rules logically in order to produce information for multipurpose [35-38]. Thus, the database system could be viewed into the data storage system throu gh optimizing computer. The software that manages the database is called the database management system (DBMS). As a result, the necessity to point out the wide range of system software should gather in enabling the users to create, maintain, control and access databases in a practical and efficient manner [39-41]. The wide range of expanding the responsibility with social concern in using the database within the DBMS pattern should be widely engaged into managing wisely and appropriately [42-44]. Through database manager, the stage of administrator needs to access the generator with its distinctive feature of data storage system through the computer devices.

\subsection{Framework}

1) Start

Begining of research

2) Title

Determining the object and the problems that will be observed

3) Introduction

Create background, problem formulation, research purpose and research benefit

4) Theoretical Basis

The theory created in research

5) Research Method

Data collection and development of information system and flowchart.

6) Discussion

Discuss the system used in the research.

7) Conclusion

The results from research made

8) End

End of research

\section{Research method}

\subsection{Data collection}

a) Observation Method

This method is used by researchers in doing observations or looking into the object of research directly by analyzing and 
evaluating the system is running to find the information needed for research materials.

b) Interview Method

This method is done by conducting a conversation between researchers and interviewees to obtain important information from an object. This interview was conducted directly to the community, government officials and related institutions to the governance system in Pringsewu District.

c) Literature Method

A literature study method is used to gain the knowledge and materials needed for research by reading reference journals and related references [8].

\subsection{SDLC method}

In this designing is used SDLC method that is changing the system and model used to develop those systems, as for steps in implementing this method is as follows

1) Planning. In this step it can be interviewed with government employees to obtain information, data collection for the needs of the system will be built

2) Analysis. In doing this analysis if the current system encounter problems or constraints then the results of its analysis can be used as a basis for improving the system.

3) Designing. Designing in making website which refers to design which have been made before.

4) Implentation. Run and operate the system that has been created [9].

\section{Implementation}

\subsection{Simple additive weighting (SAW) method}

Simple Additive Weighting method is often also known as weighted summing method. The basic concept of SAW method is to find the weighted sum of performance ratings on each alternative on all attributes. The SAW method requires the process of normalizing the decision matrix $(\mathrm{X})$ to a scale comparable to all existing alternative ratings.

$r_{i j}=\left\{\begin{array}{l}\frac{X_{i j}}{\operatorname{Max} X_{i j}} \\ \frac{\operatorname{Min} X_{i j}}{X_{i j}}\end{array}\right.$

where rij is the normalized performance rating of the $\mathrm{Ai}$ alternative on the attribute $\mathrm{Cj} ; \mathrm{i}=1,2, \ldots, \mathrm{m}$ and $\mathrm{j}=1,2, \ldots, \mathrm{n}$. The preference value for each alternative $(\mathrm{Vi})$ is given as:

$V_{i}=\sum_{j=1}^{n} w_{j} r_{i j}$

The higher $\mathrm{Vi}$ score indicates that Ai alternative is selected. In Pringsewu District it will be determined which sub District has Highest Poverty rate. There were four Criteria used in the assessment, namely:

1) $\mathrm{C} 1=$ Road facilities

2) $\mathrm{C} 2=$ Lighting source

3) $\mathrm{C} 3=$ clean water

4) $\mathrm{C} 4=$ Fuel

Decision makers assigned weight to each of the following criteria $\mathrm{C} 1=15 \% ; \mathrm{C} 2=20 \% ; \mathrm{C} 3=25 \%$; and $\mathrm{C} 4=15 \%$. There were Seven Sub-districts to be Assessed (alternatives) to determine which Sub-districts have the highest poverty levels, namely:

A1 $=$ Pardasuka Subdistrict

$\mathrm{A} 2=$ Ambarawa Subdistrict

A3 = Pagelaran Subdistrict
A5 = Sukoharjo Subdistrict

A6 = Banyumas Subdistrict

A7 = Gadingrejo Subdistrict

A8 $=$ Pringsewu Subdistrict

A9 = Adiluwih Subdistrict

\subsection{Criteria}

\subsubsection{Road facilities criteria}

Table 1 shows road facilities criteria.

Table 1: Road Facilities Criteria.

\begin{tabular}{lll}
\hline Road & Weight & Description \\
\hline Dirt road & 60 & Low \\
Underground road & 70 & Medium \\
Latasir road & 80 & Good \\
Hotmix road & 90 & Very good \\
\hline
\end{tabular}

(Source: Public Word Department, Research and Development Institution , 2004)

\subsubsection{Lighting source criteria}

Table 2 shows lighting source criteria.

Table 2: Lighting Source Criteria

\begin{tabular}{lll}
\hline Lighting & Weight & Description \\
\hline Sentir lamp & 60 & low \\
Generator lamp & 70 & medium \\
Public PLN lamp & 80 & good \\
Private PLN lamp & 90 & Very good \\
\hline
\end{tabular}

(Source: Public Word Department, Research and Development Institution , 2004)

\subsubsection{Clean water criteria}

Table 3 shows clean water criteria.

Table 3: Clean Water Criteria

\begin{tabular}{lll}
\hline Clean water & weight & Description \\
\hline River water & 60 & low \\
Spring water & 70 & medium \\
Well & 80 & good \\
PDAM & 90 & Very good \\
\hline
\end{tabular}

(Source: Public Word Department, Research and Development Institution , 2004)

\subsubsection{Fuel criteria}

Table 4 shows fuel criteria.

Table 4: Fuel Criteria

\begin{tabular}{lll}
\hline Fuel & weight & description \\
\hline fierwood & 60 & low \\
charcoal & 70 & medium \\
kerosene & 80 & good \\
LPG & 90 & Very good \\
\hline
\end{tabular}

((Source: Public Word Department, Research and Development Institution , 2004)

Table 5 shows alternative for each criteria. 
Table 5: Alternative for Each Criteria

\begin{tabular}{llllll}
\hline \multicolumn{7}{c}{ Tlternative } & Criteria \\
\hline & & C1 & C2 & C3 & C4 \\
A1 & Pardasuka Subdistrict & 90 & 80 & 80 & 80 \\
A2 & Ambarawa Subdistrict & 70 & 80 & 80 & 70 \\
A3 & Pagelaran Subdistrict & 90 & 80 & 90 & 70 \\
A4 & Pagelaran Utara Subdistrict & 90 & 80 & 90 & 70 \\
A5 & Sukoharjo Subdistrict & 70 & 80 & 90 & 90 \\
A6 & Banyumas Subdistrict & 70 & 80 & 90 & 80 \\
A7 & Gadingrejo Subdistrict & 90 & 80 & 80 & 90 \\
A8 & Pringsewu Subdistrict & 90 & 80 & 90 & 90 \\
A9 & Adiluwih Subdistrict & 90 & 80 & 80 & 70 \\
\hline
\end{tabular}

\subsection{Normalization for each criterion}

Normalization is done by dividing the alternative score of each candidate then divided by the largest score of the score of each alternative.

a) Alternative Normalization

$\mathrm{R} 1.1=\frac{90}{80}=1.125$

$\mathrm{R} 1.2=\frac{80}{80}=1$

$\mathrm{R} 1.3=\frac{80}{80}=1$

$\mathrm{R} 1.4=\frac{80}{80}=1$

b) Alternative Normalization

$\mathrm{R} 2.1=\frac{70}{90}=0.777$

$\mathrm{R} 2.2=\frac{80}{80}=1$

$\mathrm{R} 2.3=\frac{80}{80}=1$

$\mathrm{R} 2.4=\frac{70}{80}=0.875$

c) Alternative Normalization

$\mathrm{R} 3.1=\frac{90}{90}=1$

$\mathrm{R} 3.2=\frac{80}{80}=1$

$\mathrm{R} 3.3=\frac{90}{80}=1.125$

$\mathrm{R} 3.4=\frac{70}{80}=0.875$

d) Alternative Normalization

$\mathrm{R} 4.1=\frac{90}{90}=1$

$\mathrm{R} 4.2=\frac{80}{80}=1$

$\mathrm{R} 4.3=\frac{90}{80}=1.125$

$\mathrm{R} 4.4=\frac{70}{80}=0.875$

e) Alternative Normalization

$\mathrm{R} 5.1=\frac{70}{70}=1$
$\mathrm{R} 5.2=\frac{80}{80}=1$

$\mathrm{R} 5.3=\frac{90}{80}=1.125$

$\mathrm{R} 5.4=\frac{90}{80}=1.125$

f) Alternative Normalization

$\mathrm{R} 6.1=\frac{70}{70}=1$

$\mathrm{R} 6.2=\frac{80}{80}=1$

$\mathrm{R} 6.3=\frac{90}{80}=1.125$

$\mathrm{R} 6.4=\frac{80}{80}=1$

g) Alternative Normalization

$\mathrm{R} 7.1=\frac{90}{90}=1$

$\mathrm{R} 7.2=\frac{80}{80}=1$

$\mathrm{R} 7.3=\frac{80}{80}=1$

$\mathrm{R} 7.4=\frac{90}{80}=1.125$

h) Alternative Normalization

$\mathrm{R} 8.1=\frac{90}{90}=1$

$\mathrm{R} 8.2=\frac{80}{80}=1$

$\mathrm{R} 8.3=\frac{90}{80}=1.125$

$\mathrm{R} 8.4=\frac{90}{80}=1.125$

i) Alternative Normalization

$\mathrm{R} 9.1=\frac{90}{90}=1$

$\mathrm{R} 9.2=\frac{80}{80}=1$

$\mathrm{R} 9.3=\frac{80}{80}=1$

$\mathrm{R} 9.4=\frac{70}{80}=0.875$

Ranking process using weights given by the decision maker: $\mathrm{w}=$ [0.15 0.200 .250 .15$]$. The results obtained were as follows:

$\mathrm{V} 1=(0,15) *(1,125)+(0,20) *(1)+(0,25) *(1)+(0,15) *(1)$

$=0,168+0,20+0,25+0,15$

$=0.768$

$\mathrm{V} 2=$

$(0,15) *(0,777)+(0,20) *(1)+(0,25) *(1)+(0,15) *(0,875)$

$=0,116+0,20+0,25+0,131$

$=0.697$

$\mathrm{V} 3=$

$(0,15) *(1)+(0,20) *(1)+(0,25) *(1,125)+(0,15) *(0,875)$

$=0,15+0,20+0,281+0,131$ 


$$
=0.762
$$

$\mathrm{V} 4=$

$(0,15) *(1)+(0,20) *(1)+(0,25) *(1,125)+(0,15) *(0,875)$

$=0,15+0,20+0,281+0,131$

$=0.762$

$\mathrm{V} 5=$

$(0,15) *(1)+(0,20) *(1)+(0,25) *(1,125)+(0,15) *(1,125)$

$=0,15+0,20+0,281+0,168$

$=0.799$

$\mathrm{V} 6=$

$(0,15) *(1)+(0,20) *(1)+(0,25) *(1,125)+(0,15) *(1)=0,15+0,20+$

$0,281+0,15$

$=0.781$

$\mathrm{V} 7=$

$(0,15) *(1)+(0,20) *(1)+(0,25) *(1)+(0,15) *(1,125)=0,15+0,20+$

$0,25+0,168$

$=0.768$

$\mathrm{V} 8=$

$(0,15) *(1)+(0,20) *(1)+(0,25) *(1,125)+(0,15) *(1,125)=0,15+$

$0,20+0,281+0,168$

$=0.799$

$\mathrm{V} 9=$

$(0,15) *(1)+(0,20) *(1)+(0,25) *(1)+(0,15) *(0,875)=0,15+0,20+$

$0,25+0,131$

$=0.731$

\subsection{Reflection and some implications}

Referring to increasing the potential of poverty level with the innovative enhancement [45-47], adopting with possessing the reference of the government in reducing is entirely a pivotal role to give insights into the professional initiation [48-49]. The grouping manifestation has to be involved with initiating the number of tasks in maximizing the process with its potential value to achieve wisely in particular attention to sustainable enhancement [50-52]. As a result, it is necessary to look deeply into the core component of manufacturing the process with expanding the basic role of poverty criteria [53-55]. In order to gather the good result, the coordination from each component has to be involved with expanding the commitment of distinctive criteria to be more concerned with being wise and appropriate procedure stage [56-58]. The alternative point would need to achieve the approval coexistence in obtaining the best result [59-61]. In trying to get the core point of this initiative, the implementation might need to further elaborate the significant enhancement of positive distribution into expanding the social concern [62] with an innovative exposure through digital device.

\section{Conclusion}

Based on the above discussion then there was the smallest score on V2 so A2 alternative was selection alternative. In other words, Ambarawa District had the lowest score criteria, then Ambarawa Sub-district was included as poor in the sense which could be viewed as underdeveloped so that the District is expected to get special attention. It is expected that in determining a poor or underdeveloped area can be applied in other areas so that the region gets special attention from the Government in order to increase the potential of the region by adding other criteria.

\section{References}

[1] Raihana Kaplale, SP, Ms., \& Dosen. (2012). Faktor-Faktor Yang Mempengaruhi Tingkat Kemiskinan Di Kota Ambon (Study Kasus
Di Dusun Kranjang Desa Waiyame Kec. Teluk Ambon Dan Desa Waiheru Kec. Teluk Ambon Baguala Kota Ambon), 1(1), 101-115.

[2] Uning Lestari, M. T. (2017). Sistem Pendukung Keputusan Klasifikasi Keluarga Miskin Menggunakan Metode Simple Additive Weighting (SAW) Sebagai Acuan Penerima Bantuan Dana Pemerintah (Studi Kasus: Pemerintah Desa Tamanmartani, Sleman), 8, 70-78.

[3] Wijaya, Y. (2016). Implementasi Program Nasional Pemberdayaan Masyarakat (PNPM) Mandiri Dalam Menanggulangi Kemiskinan Di Kelurahan Selili Kecamatan Samarinda Ilir Kota Samarinda, 2(2), 810-821.

[4] Taufik Ramadhan, Victor G Utomo. 2014. Rancang Bangun Aplikasi Mobile Untuk Notifikasi Jadwal Kuliah Berbasis Android (Studi Kasus : STMIK Provinsi Semarang). Volume 5, No 2. Hal 48. STMIK Provinsi Semarang.

[5] Rahajo Budi. 2010. Modul Pemrograman Web (HTML, PHP, \& $M y S Q L)$. Penerbit Andi. Yogyakarta.

[6] Abdul Kadir. 2005. Pengenalan Sistem Infomasi. Penerbit Andi. Yogyakarta.

[7] Atter, S. 2000. Database Organization. Penerbit Andi. Yogyakarta.

[8] Muhamad Muslihudin, M.T.I., Elisabet YA, M.T.I, Eka Ridhawati, M.Kom., R. A. (n.d.). Perancangan Model Pengambilan Keputusan Kualitas Komplek Perumahan Di Kabupaten Pringsewu Menggunakan Fuzzy Simple Additive Weighting (SAW).

[9] Setiaji, P. (2014). Sistem Pendukung Keputusan Dengan Metode Simple Additive Weighting. Universitas Muria Kudus, 11-15.

[10] Huda, M., \& Teh, K. S. M. (2018). Empowering Professional and Ethical Competence on Reflective Teaching Practice in Digital Era. In Dikilitas, K., Mede, E., Atay D. (Eds). Mentorship Strategies in Teacher Education (pp. 136-152). Hershey, PA: IGI Global. https://doi.org/10.4018/978-1-5225-4050-2.ch007.

[11] Huda, M., Teh, K.S.M., Nor, N.H.M., and nor, M.B.M. (2018a). Transmitting Leadership Based Civic Responsibility: Insights from Service Learning. International Journal of Ethics and Systems, 34(1), 20-31. https://doi.org/10.1108/IJOES-05-2017-0079.

[12] Huda, M., Maseleno, A., Muhamad, N.H.N., Jasmi, K.A., Ahmad, A., Mustari, M.I., Basiron, B. (2018b). Big Data Emerging Technology: Insights into Innovative Environment for Online Learning Resources. International Journal of Emerging Technologies in Learning 13(1), 23-36. https://doi.org/10.3991/ijet.v13i01.6990.

[13] Huda, M., Maseleno, A., Teh, K.S.M., Don, A.G., Basiron, B., Jasmi, K.A., Mustari, M.I., Nasir, B.M., and Ahmad, R. (2018c). Understanding Modern Learning Environment (MLE) in Big Data Era. International Journal of Emerging Technologies in Learning. 13(5), 71-85. https://doi.org/10.3991/ijet.v13i05.8042.

[14] Huda, M. (2018). Empowering Application Strategy in the Technology Adoption: Insights from Professional and Ethical Engagement. Journal of Science and Technology Policy Management. https://doi.org/10.1108/JSTPM-09-2017-0044.

[15] Huda. M. \& Sabani, N. (2018). Empowering Muslim Children's Spirituality in Malay Archipelago: Integration between National Philosophical Foundations and Tawakkul (Trust in God). International Journal of Children's Spirituality, 23(1), 81-94. https://doi.org/10.1080/1364436X.2018.1431613.

[16] Huda, M., Qodriah, S.L., Rismayadi, B., Hananto, A., Kardiyati, E.N., Ruskam, A., and Nasir, B.M. (2018). Towards Cooperative with Competitive Alliance: Insights into Performance Value in Social Entrepreneurship. In Creating Business Value and Competitive Advantage with Social Entrepreneurship. (pp.294). Hershey, PA: IGI Global.

[17] Huda, M., Hehsan, A., Basuki, S., Rismayadi, B., Jasmi, K. A., Basiron, B., \& Mustari, M. I. (2019a). Empowering Technology Use to Promote Virtual Violence Prevention in Higher Education Context. In Intimacy and Developing Personal Relationships in the Virtual World (pp. 272-291). Hershey, PA: IGI Global. https://doi.org/10.4018/978-1-5225-4047-2.ch015.

[18] Huda, M., Ulfatmi, Luthfi, M.J., Jasmi, K.A., Basiron, B., Mustari, M.I., Safar, A., Embong, H.W.H., Mohamad, A.M., and Mohamed, A.K. (2019b). Adaptive online learning technology: Trends in big data era. In Diverse Learning Opportunities through TechnologyBased Curriculum Design. Hershey, PA: IGI Global. (In press).

[19] Kurniasih, D., Jasmi, K.A., Basiron, B., Huda, M., Maseleno, A. (2018). The uses of fuzzy logic method for finding agriculture and livestock value of potential village. International Journal of Engi$\begin{array}{llll}\text { neering \& Technology. } & \text { 7(3). }\end{array}$ https://doi.org/10.14419/ijet.v7i3.11984.

[20] Maseleno, A., Pardimin, Huda, M., Ramlan, Hehsan, A., Yusof, Y.M., Haron, Z., Ripin, M.N., nor, N.H.M., and Junaidi, J. (2018a). Mathematical Theory of Evidence to Subject Expertise Diagnostic. ICIC Express Letters, 12 (4), 369 DOI: 10.24507/icicel.12.04.369 
[21] Maseleno, A., Huda, M., Jasmi, K.A., Basiron, B., Mustari, I., Don, A.G., and Ahmad, R. (2018b). Hau-Kashyap approach for student's level of expertise. Egyptian Informatics Journal, https://doi.org/10.1016/j.eij.2018.04.001.

[22] Maseleno, A., Sabani, N., Huda, M., Ahmad, R., Jasmi, K.A., Basiron, B. (2018c). Demystifying Learning Analytics in Personalised Learning. International Journal of Engineering \& Technology. 7(3). 1124-1129. https://doi.org/10.14419/ijet.v7i3.9789.

[23] Moksin, A. I., Shahrill, M., Anshari, M., Huda, M., \& Tengah, K. A. (2018b). The Learning of Integration in Calculus Using the Autograph Technology. Advanced Science Letters, 24(1), 550-552. https://doi.org/10.1166/asl.2018.12067.

[24] Putra, D.A.D., Jasmi, K.A., Basiron, B., Huda, M., Maseleno, A., Shankar, K., Aminudin, N. (2018). Tactical Steps for EGovernment Development. International Journal of Pure and Applied Mathematics.119 (15). 2251-2258

[25] Rosli, M.R.B., Salamon, H.B., and Huda, M. (2018). Distribution Management of Zakat Fund: Recommended Proposal for Asnaf Riqab in Malaysia. International Journal of Civil Engineering and Technology 9(3), pp. 56-64.

[26] Sugiyarti, E., Jasmi, K.A., Basiron, B., Huda, M., Shankar, K., Maseleno, A. (2018). Decision support system of scholarship grantee selection using data mining. International Journal of Pure and Applied Mathematics.119 (15), 2239-2249.

[27] Sundari, E., Jasmi, K.A., Basiron, B., Huda, M., and Maseleno, A. (2018). Web-Based Decision Making System for Assessment of Employee Revenue using Weighted Product. International Journal of Engineering and Technology.

[28] Susilowati, T., Jasmi, K.A., Basiron, B., Huda, M., Shankar, K., Maseleno, A., Julia, A., Sucipto. (2018). Determination of Scholarship Recipients Using Simple Additive Weighting Method. International Journal of Pure and Applied Mathematics.119 (15), 22312238.

[29] Anshari, M., Almunawar, M. N., Shahrill, M., Wicaksono, D. K., \& Huda, M. (2017). Smartphones usage in the classrooms: Learning aid or interference Education and Information Technologies, 22(6), 3063-3079. https://doi.org/10.1007/s10639-017-9572-7.

[30] Huda, M., Sabani, N., Shahrill, M., Jasmi, K. A., Basiron, B., \& Mustari, M. I. (2017a). Empowering Learning Culture as Student Identity Construction in Higher Education. In A. Shahriar, \& G. Syed (Eds.), Student Culture and Identity in Higher Education (pp. 160-179). Hershey, PA: IGI Global. https://doi.org/10.4018/978-15225-2551-6.ch010.

[31] Huda, M., Jasmi, K. A., Hehsan, A., Shahrill, M., Mustari, M. I., Basiron, B., \& Gassama, S. K. (2017b). Empowering Children with Adaptive Technology Skills: Careful Engagement in the Digital Information Age. International Electronic Journal of Elementary Education, 9(3), 693-708.

[32] Huda, M., Shahrill, M., Maseleno, A., Jasmi, K. A., Mustari, I., \& and Basiron, B. (2017c). Exploring Adaptive Teaching Competencies in Big Data Era. International Journal of Emerging Technologies in Learning, 12(3), 68-83. https://doi.org/10.3991/ijet.v12i03.6434.

[33] Huda, M., Jasmi, K. A., Basiran, B., Mustari, M. I. B., \& Sabani, A. N. (2017d). Traditional Wisdom on Sustainable Learning: An Insightful View From Al-Zarnuji's Ta 'lim al-Muta 'allim. SAGE Open, 7(1), 1-8. https://doi.org/10.1177/2158244017697160.

[34] Huda, M., Jasmi, K. A., Embong, W. H., Safar, J., Mohamad, A. M., Mohamed, A. K., Muhamad, N. H., Alas, Y., \& Rahman, S. K. (2017e). Nurturing Compassion-Based Empathy: Innovative Approach in Higher Education. In M. Badea, \& M. Suditu (Eds.), Violence Prevention and Safety Promotion in Higher Education Settings (pp. 154-173). Hershey, PA: IGI Global. https://doi.org/10.4018/978-1-5225-2960-6.ch009.

[35] Huda, M., Jasmi, K. A., Alas, Y., Qodriah, S. L., Dacholfany, M. I., \& Jamsari, E. A. (2017f). Empowering Civic Responsibility: Insights From Service Learning. In S. Burton (Ed.), Engaged Scholarship and Civic Responsibility in Higher Education(pp. 144165). Hershey, PA: IGI Global. https://doi.org/10.4018/978-1-52253649-9.ch007.

[36] Huda, M., Jasmi, K. A., Mustari, M. I., Basiron, B., Mohamed, A K., Embong, W., ... \& Safar, J. (2017g). Innovative E-Therapy Service in Higher Education: Mobile Application Design. International Journal of Interactive Mobile Technologies, 11(4), 83-94. https://doi.org/10.3991/ijim.v11i4.6734.

[37] Huda, M., Jasmi, K. A., Mustari, M. I., \& Basiron, B. (2017h) Understanding Divine Pedagogy in Teacher Education: Insights from Al-zarnuji's Ta'lim Al-Muta'Allim. The Social Sciences, 12(4), 674-679.
[38] Huda, M., Jasmi, K. A., Mustari, M. I. B., \& Basiron, A. B. (2017i). Understanding of Wara' (Godliness) as a Feature of Character and Religious Education. The Social Sciences, 12(6), 1106-1111.

[39] Huda, M., Siregar, M., Ramlan, Rahman, S.K.A., Mat Teh, K.S., Said, H., Jamsari, E.A., Yacub, J., Dacholfany, M.I., \& Ninsiana, W. (2017j). From Live Interaction to Virtual Interaction: An Exposure on the Moral Engagement in the Digital Era. Journal of Theoretical and Applied Information Technology , 95(19), 49644972.

[40] Huda, M., Maseleno, A., Jasmi, K. A., Mustari, I., \& Basiron, B. (2017k). Strengthening Interaction from Direct to Virtual Basis: Insights from Ethical and Professional Empowerment. International Journal of Applied Engineering Research, 12(17), 6901-6909.

[41] Huda, M., Haron, Z., Ripin, M. N., Hehsan, A., \& Yaacob, A. B. C. (20171). Exploring Innovative Learning Environment (ILE): Big Data Era. International Journal of Applied Engineering Research, 12(17), 6678-6685

[42] Maseleno, A., Huda, M., Siregar, M., Ahmad, R., Hehsan, A., Haron, Z., Ripin, M.N., Ihwani, S.S., and Jasmi, K.A. (2017). Combining the Previous Measure of Evidence to Educational Entrance Examination. Journal of Artificial Intelligence 10(3), 8590. https://doi.org/10.3923/jai.2017.85.90.

[43] Huda, M., Anshari, M., Almunawar, M. N., Shahrill, M., Tan, A., Jaidin, J. H., \& Masri, M. (2016a). Innovative Teaching in Higher Education: The Big Data Approach. The Turkish Online Journal of Educational Technology, 15(Special issue), 1210-1216.

[44] Huda, M., Yusuf, J. B., Jasmi, K. A., \& Nasir, G. A. (2016b). Understanding Comprehensive Learning Requirements in the Light of al-Zarnūjī’s Ta‘'īm al-Muta'allim. Sage Open, 6(4), 1-14. https://doi.org/10.1177/2158244016670197.

[45] Huda, M., Yusuf, J. B., Jasmi, K. A., \& Zakaria, G. N. (2016c). AlZarnūjì's Concept of Knowledge ('ilm). SAGE Open, 6(3), 1-13. https://doi.org/10.1177/2158244016666885.

[46] Huda, M., Jasmi, K. A., Mohamed, A. K., Wan Embong, W. H., \& and Safar, J. (2016d). Philosophical Investigation of Al-Zarnuji's Ta'lim al-Muta'allim: Strengthening Ethical Engagement into Teaching and Learning. Social Science, 11(22), 5516-551.

[47] Kartanegara, M., \& Huda, M. (2016). Constructing Civil Society: An Islamic Cultural Perspective. Mediterranean Journal of Social Science, 7(1), 126-135.

[48] Othman, R., Shahrill, M., Mundia, L., Tan, A., \& Huda, M. (2016). Investigating the Relationship between the Student's Ability and Learning Preferences: Evidence from Year 7 Mathematics Students. The New Educational Review, 44(2), 125-138.

[49] Adela, A., Jasmi, K.A., Basiron, B., Huda, M., Maseleno, A. (2018) Selection of dancer member using simple additive weighting. International Journal of Engineering \& Technology. 7(3). 1096-1107. https://doi.org/10.14419/ijet.v7i3.11983.

[50] Aminin, S., Huda, M., Ninsiana, W., and Dacholfany, M.I. (2018). Sustaining civic-based moral values: Insights from language learning and literature. International Journal of Civil Engineering and Technology. 9(4), 157-174.

[51] Amin, M.M., Nugratama, M.A.A., Maseleno, A., Huda, M., Jasmi, K.A., (2018). Design of cigarette disposal blower and automatic freshner using mq-5 sensor based on atmega 8535 microcontroller. International Journal of Engineering \& Technology. 7(3). 11081113 https://doi.org/10.14419/ijet.v7i3.11917.

[52] Atmotiyoso, P. and Huda, M. (2018). Investigating Factors Influencing Work Performance on Mathematics Teaching: A Case Study. International Journal of Instruction. 11(3), 391-402. https://doi.org/10.12973/iji.2018.11327a.

[53] Wulandari, Aminin, S., Dacholfany, M.I., Mujib, A., Huda, M., Nasir, B.M., Maseleno, A., Sundari, E., Fauzi, Masrur, M., Design of Library Information Systems. International Journal of Engineering and Technology (UAE) (In Press).

[54] Susilowati, T., Teh, K.S.T., Nasir, B.M., Don, A.G., Huda, M., Hensafitri, T., Maseleno, A., Oktafianto, Irawan, D. Learning Application of Lampung Language Based on Multimedia Software. International Journal of Engineering and Technology (UAE) (In Press).

[55] Abadi, S., Teh, K.S.M., Nasir, B.M., Huda, M., Ivanova, N.L., Sari, T.I., Maseleno, A., Satria, F., Muslihudin, M. Application Model of K-Means Clustering Insights into Promotion Strategy of Vocational High School. International Journal of Engineering and Technology (UAE) (In Press).

[56] Susilowati, T., Dacholfany, M.I., Aminin, S., Ikhwan, A., Nasir, B.M., Huda, M., Prasetyo, A., Maseleno, A., Satria, F., Hartati, S., Wulandari. Getting Parents Involved in Child's School: Using Attendance Application System Based on SMS Gateway. International Journal of Engineering and Technology (UAE) (In Press). 
[57] Aminudin, N., Huda, M., Ihwani, S.S., Noor, S.S.M., Basiron, B. Jasmi, K.A., Safar, J., Mohamed, A.K., Embong, W.H.W., Mohamad, A.M., Maseleno, A., Masrur, M., Trisnawati, Rohmadi, D. The Family Hope Program using AHP Method. International Journal of Engineering and Technology (UAE) (In Press).

[58] Aminudin, N., Fauzi, Huda, M., Hehsan, A., Ripin, M.N., Haron, Z., Junaidi, J., Irviani, R., Muslihudin, M., Hidayat, S., Maseleno, A., Gumanti, M., Fauzi, A. Application Program Learning Based on Android for Students' Experiences. International Journal of Engineering and Technology (UAE) (In Press).

[59] Abadi, S., Teh, K.S.M., Huda, M., Hehsan, A., Ripin, M.N., Haron, Z., Muhamad, N.H.N., Rianto, R., Maseleno, A., Renaldo, R., Syarifudin, A. Design of student score application for assessing the most outstanding student at vocational high school. International Journal of Engineering and Technology (UAE) (In Press).

[60] Aminudin, N., Huda, M., Kilani, A., Embong, W.H.W., Mohamed, A.M., Basiron, B., Ihwani, S.S., Noor, S.S.M., Jasmi, K.A., Safar, J., Ivanova, N.L., Maseleno, A., Triono, A., Nungsiati. Higher Education Selection using Simple Additive Weighting. International Journal of Engineering and Technology (UAE) (In Press).

[61] Abadi, S., Huda, M., Jasmi, K.A., Noor, S.S.M., Safar, J., Mohamed, A.K., Embong, W.H.W., Mohamad, A.M., Hehsan, A., Basiron, B., Ihwani, S.S., Maseleno, A., Muslihudin, M., Satria, F., Irawan, D., Hartati, S. Determination of the Best Quail Eggs using Simple Additive Weighting. International Journal of Engineering and Technology (UAE) (In Press).

[62] Abadi, S., Huda, M., Hehsan, A., Mohamad, A.M., Basiron, B., Ihwani, S.S., Jasmi, K.A., Safar, J., Mohamed, A.K., Embong, W.H.W., Noor, S.S.M., Brahmono, B., Maseleno, A., Fauzi, A., Aminudin, N., Gumanti, M. Design of online transaction model on traditional industry in order to increase turnover and benefits. International Journal of Engineering and Technology (UAE) (In Press).

[63] Abadi, S., Huda, M., Basiron, B., Ihwani, S.S., Jasmi, K.A., Hehsan, A., Safar, J., Mohamed, A.K., Embong, W.H.W., Mohamad, A.M., Noor, S.S.M., Novita, D., Maseleno, A., Irviani, R., Idris, M., Muslihudin, M. Implementation of Fuzzy Analytical Hierarchy Process on Notebook Selection. International Journal of Engineering and Technology (UAE) (In Press). 